\title{
PENATAAN REKLAME KAMPUS UIN ALAUDDIN MAKASSAR DENGAN PENDEKATAN SISTEM INFORMASI GEOAGRAFIS
}

\author{
Fadhil Surur $^{1}$, Faridah Yusuf ${ }^{2}$ \\ ${ }^{1}$ Jurusan Teknik Perencanaan Wilayah dan Kota \\ ${ }^{2}$ Jurusan Sistem Informasi \\ Fakultas Sains dan Teknologi UIN Alauddin Makassar \\ E-mail: fadhil.surur@uin-alauddin.ac.id
}

\begin{abstract}
Abstrak: Perkembangan kawasan dan aktivitas warga kampus yang signifikan mendorong penataan lanskap kurang memadai. Salah satunya adalah permasalahan reklame yang mengurangi citra visual dan lanskap kawasan. Sebagian besar reklame terpasang tanpa adanya pengawasan dari pihak kampus, sehingga pada momentum tertentu misalnya pada saat penerimaan mahasiswa baru akan terjadi overlapping pemasangan reklame. Selain itu terdapat kebiasaan mahasiswa yang menampilkan visual reklame yang kurang sesuai dengan tatanan akademik di UIN Alauddin Makassar. Sejauh ini perkembangan teknologi telekomunikasi dan informatika (telematika) sangat dimungkinkan untuk melakukan integrasi teknologi dan penataan reklame dalam kampus. Langkah awal yang dapat dilakukan adalah mengidentifikasi lokasi di dalam Kampus UIN Alauddin Makassar yang prioritas untuk dijadikan sebagai lokasi pemasangan reklame kampus. Rancangan dan pelaksanaan penelitian dilakukan dengan metode deskriptif dengan jenis metode studi kasus dengan menggunakan data sekunder dan data primer. Teknik analisis yang digunakan mencakup analisis secara kualitatif dan analisis hirarki proses. Hasil penelitian diperoleh pemasangan reklame cenderung tidak beraturan dan tidak sesuai dengan teknis pemasangan terhadap kondisi lingkungan sekitar. Kondisi ini mendorong munculnya visual negatif pada 4 segmen yang mempunyai fungsi bangunan penting dan nilai vital dalam lingkungan kampus.
\end{abstract}

Kata Kunci: Lanskap, Reklame, UIN Alauddin Makassar

\section{PENDAHULUAN}

anskap suatu kawasan merupakan pertimbangan penting dalam perencanaan dan pengelolaan kawasan. Dalam konsep pengelolaan kawasan dikenal dengan sense of place yaitu sebuah konsep untuk menelusuri preferensi, pemaknaan maupun partisipasi dalam pengelolaan kawasan. Sense of place juga berhubungan dengan peningkatan visual lanskap dalam rangka mencegah situasi undervalued dimana potensi lanskap menjadi sumberdaya umum yang dapat diabadikan karena aktivitas manusia (Djayaningrat, 2011). Kawasan kampus UIN Alauddin Makassar dapat dinilai sebuah lanskap yang memiliki ciri khas tersendiri. Pada umumnya lanskap di kawasan ini terdiri dari bangunan dan didukung dengan jenis tanaman hijau maupun prasarana penunjang lainnya. 
Perkembangan kawasan dan aktivitas warga kampus yang signifikan mendorong penataan lanskap kurang memadai. Salah satunya adalah permasalahan reklame yang mengurangi citra visual dan lanskap kawasan. Sebagian besar reklame terpasang tanpa adanya pengawasan dari pihak kampus, sehingga pada momentum tertentu misalnya pada saat penerimaan mahasiswa baru akan terjadi overlapping pemasangan reklame. Selain itu terdapat kebiasaan mahasiswa yang menampilkan visual reklame yang kurang sesuai dengan tatanan akademik di UIN Alauddin Makassar.

Pada kenyataan saat ini, perkembangan reklame muncul sebagai salah satu dampak negatif yang memperburuk tampilan visual kawasan (Juniarko, Surjono, \& Usman, 2010). Perancangan kawasan berkaitan dengan tanggapan inderawi manusia terhadap lingkungan fisik yang mencakup penampilan visual, kualitas estetika dan karakter spasial (Branch, 1996). Terjadinya pemasangan reklame yang berlebihan terutama pada masa penerimaan mahasiswa baru, dianggap sebuah tradisi penyambutan yang setiap tahun harus dilaksanakan. Pada kenyataanya reklame akan terpasang sepanjang jalan koridor utama, taman-taman kampus hingga bagian gedung perkuliahan. Hal ini mendorong menurunnya citra visual lanskap kawasan kampus, pada sisi yang berbeda menimbulkan sampah pada akhir kegiatan penyambutan mahasiswa baru. Disisi lain media publikasi reklame di kawasan ini hanya tersedia bagian depan gerbang, yang kapasitasnya kurang memadai. Sehingga cenderung overload atau kelebihan kapasitas.

Kondisi seperti ini diperburuk oleh belum adanya aturan khusus terkait dengan pedoman teknis pemasangan reklame di dalam lingkungan kampus. Selain itu belum tersedianya standar operasional prosedur (SOP) pemasangan reklame berserta sistem pengawasannya. Hal ini dikarenakan belum adanya dasar penentuan pemasangan reklame yang sesuai dengan aturan. Seringkali terjadi pemasangan unit reklame baru pada lokasi yang sama padahal dari segi kuantitas sudah tidak layak dilakukan pemasangan karena hanya mengakibatkan penumpukan. Penumpukan reklame dan cenderung tidak teratur ditemukan pada beberapa lokasi, seperti di gerbang pintu 1 dan pintu 2, jalur utama depan Fakultas Sains dan Teknologi hingga ke sekitaran masjid kampus.

Sejauh ini perkembangan teknologi telekomunikasi dan informatika (telematika) sangat dimungkinkan untuk melakukan integrasi teknologi dan penataan reklame dalam kampus. Langkah awal yang dapat dilakukan adalah mengidentifikasi lokasi di dalam Kampus UIN Alauddin Makassar yang prioritas untuk dijadikan sebagai lokasi pemasangan reklame kampus. Selanjutnya melakukan database berbasis sistem informasi geografis terhadap lokasi yang telah direkemondasikan untuk pemasangan reklame. Tujuan penelitian ini terdiri dari mengindentifikasi kondisi eksisting pemasangan reklame dalam kampus UIN Alauddin Makassar dan selanjutnya menentukan lokasi yang prioritas untuk penempatan media reklame berdasarkan pendekatan sistem informasi geografis.

\section{METODE PENELITIAN}

\section{A. Lokasi dan Waktu Penelitian}

Penelitian dilakukan di Kawasan Kampus II UIN Alauddin Makassar yang terletak di Kelurahan Romang Polong Kecamatan Somba Opu Kabupaten Gowa. Penelitian dilaksanakan pada bulan Mei hingga Oktober 2018. Pemilihan Lokasi Penelitian 
dilakukan secara sengaja (purposive) mengingat kawasan kampus merupakan satu kesatuan sistem lingkungan pendidikan. Oleh karena itu kawasan tersebut memerlukan strategi penataan reklame.

\section{B. Desain Penelitian}

Rancangan dan pelaksanaan penelitian dilakukan dengan metode deskriptif dengan jenis metode studi kasus. Metode deskriptif adalah pencarian fakta dengan interpretasi yang tepat terhadap status kelompok manusia, suatu objek, suatu set kondisi, suatu sistem pemikiran dan suatu kelas peristiwa. Metode studi kasus merupakan prosedur dan teknik penelitian tentang subjek yang diteliti berupa individu, lembaga, kelompok atau masyarakat, dengan tujuan untuk memperoleh gambaran secara rinci tentang latar belakang, sifat-sifat serta karakter-karakter yang khas dari kasus, ataupun status dari individu yang kemudian akan dijadikan suatu hal yang bersifat umum. Objek penelitian ini adalah kawasan kampus II UIN Alauddin dan yang menjadi subjek atau narasumber adalah orang-orang yang menjadi kunci adalah warga kampus dan pihak-pihak yang dapat mendukung dalam memperoleh data serta informasi.

\section{Jenis dan Sumber Data}

Jenis data yang digunakan mencakup data primer dan data sekunder. Data primer diperoleh dari hasil pengamatan langsung di lapangan, observasi, wawancara dan kuisioner, pengambilan data koordinat, serta dokumentasi atau sketsa maupun visual berupa gambar dan foto. Data sekunder diperoleh dari sumber tertulis yang telah ada berkaitan dengan materi yang akan dicari seperti dari buku, laporan, peta dan data instansional di kampus UIN Alauddin Makassar.

\section{Teknik Pengumpulan Data}

Data primer didapatkan melalui wawancara langsung didukung dengan penggunaan kuesioner kepada pimpinan universitas, dekan, mahasiswa, dosen, pegawai, pihak keamanan, kantin dan petugas kebersihan. Kuesioner yang digunakan diadaptasi dari penelitian terdahulu dengan memperhatikan kesesuaian faktor terkait objek penelitian. Data yang digunakan adalah data yang mendukung analisis mengenai pemilihab lokasi pemasangan reklame. Data sekunder diperoleh dari penelusuran lain berasal dari kepustakaan, buku, skripsi, kebijakan grand design kampus dan data relevan lainnya.

Kondisi dan situasi saat pelaksanaan penelitian cukup kondusif sehingga metode Focus Group Discussion (FGD) dapat gunakan sebanyak satu kali dalam pelaksanaannya. FGD dilaksanakan bersasarkan ketersediaan data dan kesediaan narasumber dalam memberikan informasi. Observasi dilaksanakan beberapa kali berdasarkan kondisi lingkungan. Wawancara secara terfokus dilaksanakan dengan panduan daftar pertanyaan.

Survei GPS Pengumpulan data koordinat dilakukan dengan melakukan survey objek dengan menggunakan alat GPS (Global Positioning System). GPS adalah suatu sistem navigasi yang memanfaatkan satelit. Data-data yang diambil berbentuk titik pemasangan reklame. Data waypoints bersifat seperti titik yang menginformasikan posisi secara akurat dan tepat mengenai pemasangan reklame. 


\section{E. Populasi dan Sampel}

Jenis populasi yang digunakan pada penelitian ini adalah seluruh warga kampus UIN Alauddin Makassar, dengan teknik pengambilan sampel secara purposive sampling (pengambilan sampel yang disengaja) yaitu memilih 55 sampel yang dianggap relevan dan mampu memberikan jawaban yang valid. Distribusi sampel mencakup 10 sampel mahasiswa, 10 sampel dosen, 10 sampel pegawai, 10 sampel petugas kantin / keamanan/ kebersihan, dan 15 sampel dari unsur pimpinan atau pengambil kebijakan. Pengisian kusioner AHP dilakukan dengan menuntun seluruh responden sesuai dengan petunjuk setiap pertanyaan yang diajukan.

\section{F. Metode Analisis}

1. Analisis Deskriptif

Metode analisis deskriptif digunakan untuk menggambarkan kondisi eksisting reklame terpasang dan karakteristik fisik setiap segmen yang teridentifikasi. Analisis evaluatif digunakan untuk menilai apakah kondisi eksisting reklame terpasang mengganggu kondisi lanskap kawasan kampus UIN Alauddin Makassar.

2. Analisis Hirarki Proses

Kerangka AHP merupakan kerangka kerja untuk mendapat hasil prioritas dalam penyusunan generic porter strategy. Kerangka kerja formulasi strategi yang terdiri atas tiga tahapan menurut David (2009), yaitu:

- Tahap Masukan (Input Stage). Tahap meringkas informasi atau input dasar yang diperlukan dalam menentukan lokasi yang ideal dari nilai tertinggi perhitungan. Input yang didapat dari pendekatan Porter diamond model dan Porter five force. Analisis ini dilakukan untuk mengidentifikasi beragam faktor eksternal-internal yang mempengaruhi nilai akhir. Keunggulan tersebut memiliki pengaruh signifikan terhadap perusahaan dalam mencapai tujuan yang telah ditetapkan.

- Tahap Pencocokan (Matching Stage). Tahap ini memfokuskan dan menghasilkan alternatif lokasi yang terpilih. Tahap pencocokan ini menggunakan alat analisis Three Generic Porter. Alat ini berfungsi untuk menganalisis posisi relatif dalam Generic Porter Strategy. Mencocokkan faktor-faktor keunggulan internal dan eksternal dengan Generic Porter Strategy adalah kunci untuk menghasilkan alternatif lokasi yang layak dan efektif pada penelitian ini.

- Tahap Pemilihan Strategi (Decision Stage). Tahap pemilihan strategi berdasarkan sejumlah alternatif strategi yang telah ditetapkan. Metode yang digunakan pada tahap ini adalah nilai tertinggi dari perhitungan Analytical Hierarchy Process (AHP). Setelah komponen-komponen pemilihan strategi telah diperoleh dengan jelas, tahap selanjutnya menetapkan komponen yang paling diprioritaskan untuk dijalankan sesuai perhitungan AHP.

\section{HASIL DAN PEMBAHASAN}

\section{A. Kondisi dan Keberadaan Reklame}

Secara umum kondisi reklame di Kawasan Kampus II UIN Alauddin Makassar termasuk bervariasi, tergantung kondisi dan nilai strategis suatu jalur. Jenis reklame yang dapat ditemui di dalam lingkungan kampus ini dapat dibedakan menjadi:

1. Reklame Permanen

Jenis reklame yang dipasang dalam kawasan Kampus II UIN Alauddin Makassar 
yang berdurasi lama (minimal dalam 1 tahun) dengan jenis billboard tanam maupun tempel. Hasil identifikasi di lapangan pemasangan reklame permanen dilakukan oleh pihak kampus antara lain reklame tata tertib dan kode etik UIN Alauddin Makassar yang terpasang pada beberapa titik, billboard Bank BNI dan BRI (baik di pintu 1 dan dua maupun di gerai ATM), serta reklame kantin misal di kafetaria (samping gedung rektorat).
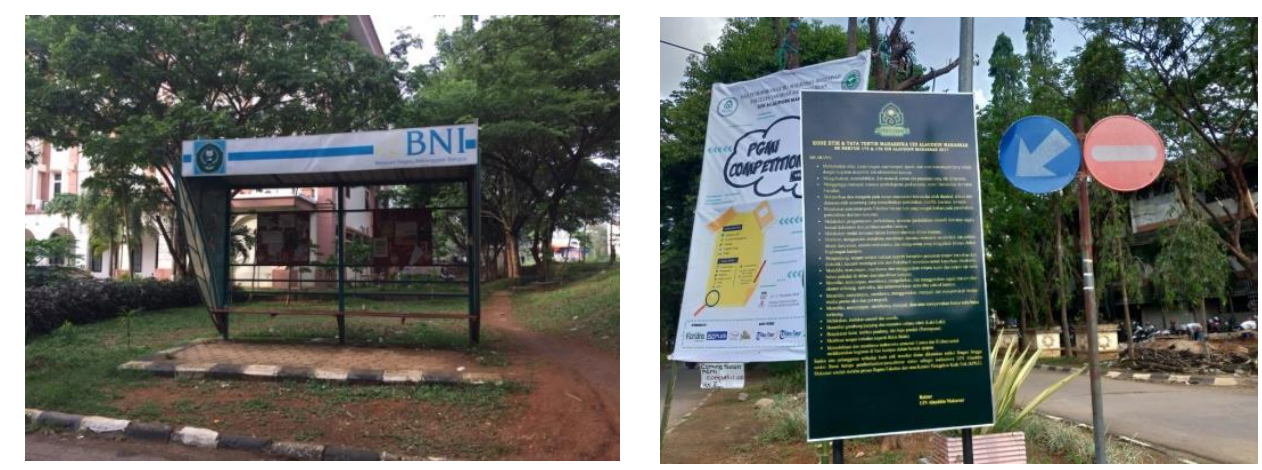

Gambar 1. Jenis reklame permanen

2. Reklame Temporer

Jenis reklame yang bersifat sementara atau berdurasi pendek (mingguan atau bulanan). Sedangkan yang termasuk reklame temporer atau berdurasi pendek antara lain spanduk, umbul-umbul, poster, banner kain, baliho, dan bangunan 3 dimensi. Informasi yang disampaikan pada jenis reklame temporer cenderung beragam antara lain informasi event, ucapan selamat datang maupun informasi perekrutan UKM serta informasi lainnya. Pemasangan reklame temporer biasanya mengikuti kalender akademik yang berlaku. Pada saat musim penerimaan mahasiswa baru maka akan semakin banyak jenis reklame temporer yang terpasang.

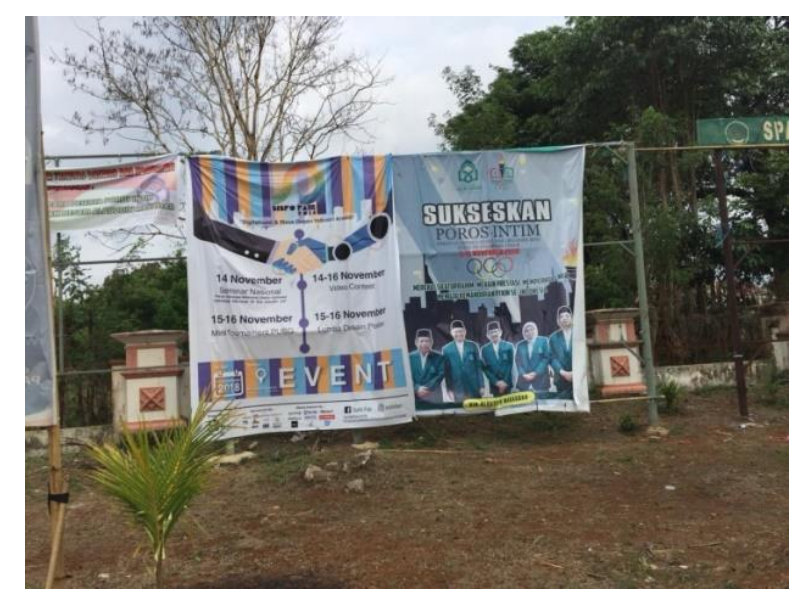

Gambar 2. Jenis reklame temporer (informasi kegiatan)

\section{B. Karakteristik Pemasangan Reklame}

Proses identifikasi karakteristik pemasangan reklame dilakukan berdasarkan pembagian segmen dalam kawasan kampus II UIN Alauddin Makassar. Pembagian segmen mengacu pada karakteristik yang meliputi beberapa elemen perancangan kota, 
yaitu penggunaan lahan, sirkulasi, kondisi dan sebaran bangunan, ruang terbuka (vegetasi), dan jalur pedestrian.

\section{a. Segmen 1}

Segmen ini terdiri dari kesatuan kawasan yang meliputi bangunan auditorium, gedung LP2M, rencana gedung Pascasarjana, taman dan kolam rektorat. Antar bangunan dihubungkan dengan 2 jalur jalan. Total luas segmen 1 mencapai 2,88 ha. Pada segmen ini tidak termanfaatkan untuk kegiatan pemasangan reklame, karena secara umum segmen ini memiliki sirkulasi manusia yang kurang dan periodik yaitu hanya pada kegiatan wisuda maupun kegiatan lain yang dilaksanakan di auditorium.

b. Segmen 2

Segmen ini terdiri dari kesatuan kawasan yang meliputi gerbang pintu 1, pos jaga, lapangan upacara dan gedung rektorat. Antar bangunan dihubungkan dengan 2 jalur jalan. Total luas segmen 2 mencapai 2,32 ha. Tersedia media pemasangan reklame pada sisi kiri jalan utama (kendaraan roda dua). Segmen ini merupakan segmen yang paling diminati untuk pemasangan reklame baik temporer maupun permanen karena dapat menarik perhatian secara langsung sesaat memasuki kawasan kampus. Saat ini terpasang 2 reklame permanen Bank BRI dan Bank BNI di sisi depan pintu 1.

\section{c. Segmen 3}

Segmen ini terdiri dari kesatuan kawasan yang meliputi rencanan pembangunan masjid agung Alauddin, gedung dosen, bangunan Fakultas Sains dan Teknologi, dan bangunan Fakultas Ushuluddin, Filsafat dan Ilmu Politik dengan total luas segmen 3 mencapai 6,22 ha. Tersedia media reklame permanen berupa Kode Etik dan Tata Tertib Mahasiswa. Segmen ini juga merupakan segmen yang paling diminati untuk pemasangan reklame baik temporer maupun permanen. Jalur arteri yang terhubung dengan sirkulasi segmen 1 memudahkan pengguna jalan untuk membaca informasi yang terpasang. Selain itu terdapat berbagai jenis pepohonan yang dimanfaatkan untuk media pemasangan reklame. Saat ini terpasang reklame permanen Bank BRI di sisi depan pintu 1.

d. Segmen 4

Segmen ini terdiri dari kesatuan kawasan yang meliputi bangunan pintu 2, gedung Fakultas Ekonomi dan Bisnis Islam, bangunan perdagangan dan jasa, gedung CBT, poliklinik dan bangunan Fakultas Kedokteran dan Ilmu Kesehatan. Luas total segmen 4 adalah 4,59 ha. Tersedia media reklame permanen berupa reklame Bank BRI dan Bank BNI. Segmen ini juga merupakan segmen yang paling diminati untuk pemasangan reklame baik temporer maupun permanen. Jalur arteri yang terhubung dengan sirkulasi segmen 1 dan segmen 2 memudahkan pengguna jalan untuk membaca informasi yang terpasang. Keberadaan pintu 2 menjadi jalur penting keluar dari kampus UIN Alauddin.

e. Segmen 5

Segmen ini terdiri dari kesatuan kawasan yang meliputi lapangan olahraga, gedung LPM, dan bangunan Fakulas Syariah dan Hukum. Luas total segmen 4 yaitu 4,62 ha. Tersedia media reklame permanen berupa kode etik dan tata tertib mahasiswa. Segmen ini juga terpasang reklame temporer di sisi kiri dan kanan jalan. Di sisi lapangan olahraga juga dimanfaatkan sebagai media pemasangan reklame, sehingga mempengaruhi citra visual pada segmen ini. 


\section{f. Segmen 6}

Segmen ini terdiri dari kesatuan kawasan yang meliputi gedung PKM, bangunan Fakultas Dakwah dan Komunikasi, bangunan Fakulas Adab dan Humaniora, masjid kampus, gedung dosen, perpustakaan, cafeteria dan gedung rusun mahasiswa. Sistem sirkulasi jalan sekunder menghubungkan antarbangunan dalam segmen ini. Selain itu fungsi pedestrian juga cukup bermanfaat dalam mendukung pola sirkulasi pejalan kaki. Luas total segmen 6 mencapai 3,43 ha. Segmen ini juga terpasang reklame temporer di sisi kiri dan kanan jalan, namun intensitasnya lebih rendah dibanding segmen lain. Pada segmen ini terdapat taman masjid kampus yang dimanfaatkan untuk pemasangan reklame.

g. Segmen 7

Segmen ini terdiri dari kesatuan kawasan yang meliputi gedung Fakultas Tarbiyah dan Keguruan, gedung perkuliahan umum, dan rumah susun mahasiswa. Selain itu terdapat beberapa kegiatan perdagangan dan jasa serta laboratorium lapangan. Luas total segmen 7 adalah 3,79 ha.Di depan Fakultas Tarbiyah dan Keguruan terdapat 1 unit spanduk centre yang memuat informasi kegiatan di FTK. Segmen ini juga terpasang reklame temporer di sisi kiri dan kanan jalan. Segmen 7 merupakan segmen dengan intensitas pemasangan reklame yang paling rendah dibandingkan dengan segmen yang lain, karena pola sirkulasi manusia dan kendaraan lebih sedikit.

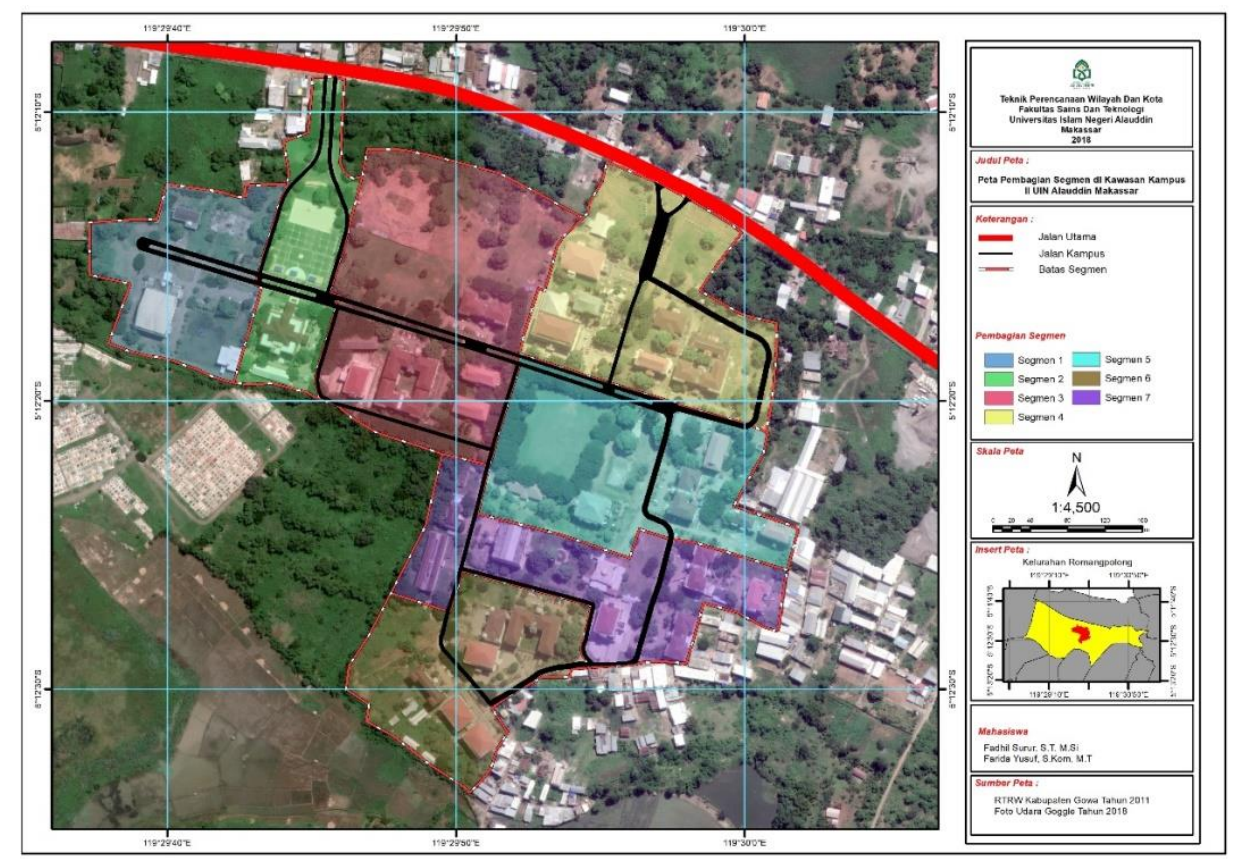

Gambar 3. Peta pembagian segmen

\section{Dampak Visual Negatif}

Pada segmen vital (segmen 2, segmen 3, segmen 4 dan segmen 5) terjadi pemasangan reklame yang berdampak visual negatif yang disebabkan karena tidak terjadi kesesuaian lokasi pemasangan dengan kondisi lingkungan sekitar. Pada segmen 2 merupakan welcoming area dalam lingkungan kampus, artinya view pertama ketika memasuki kawasan kampus terdapat pada segmen ini. Lanskap lapangan upacara dan gedung rektorat seharusnya tidak boleh terhalang dengan pemasangan reklame secara 
berlebihan sehingga menutupi lanskap secara umum.

Pada segmen 3 dengan fungsi bangunan perkuliahan juga terjadi visual negatif yang berdampak pada penurunan citra lingkungan. Lanskap hijau dengan jenis pepohonan yang rindang terhalang dengan pemasangan reklame yang tidak beraturan. Pemasangan reklame sepanjang jalan memanfaatkan sempadan jalan secara berlebihan. Kondisi ini juga terjadi pada segmen 4, pemasangan reklame menumpuk pada bagian pintu 2 kampus UIN Alauddin Makassar. Lanskap bangunan pintu 2 terhalang oleh pemasangan reklame yang berlebihan. Citra visual ini menurun jika arah pandangan dari luar kampus.
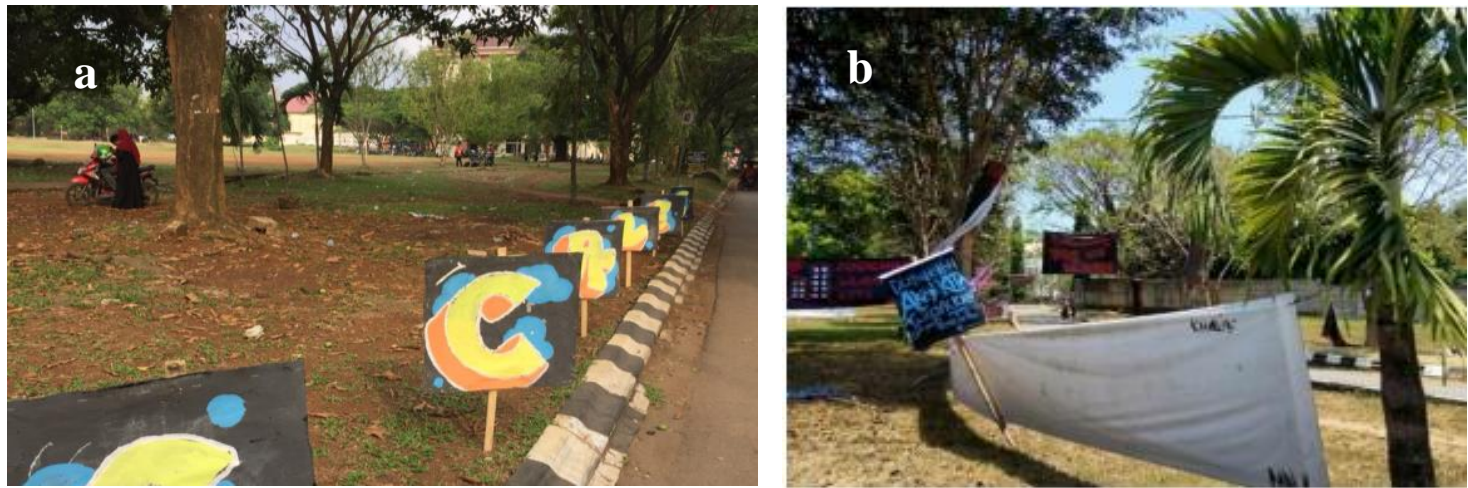

Gambar 4. Visual negatif pada segmen 2 (a) dan segmen 3 (b)

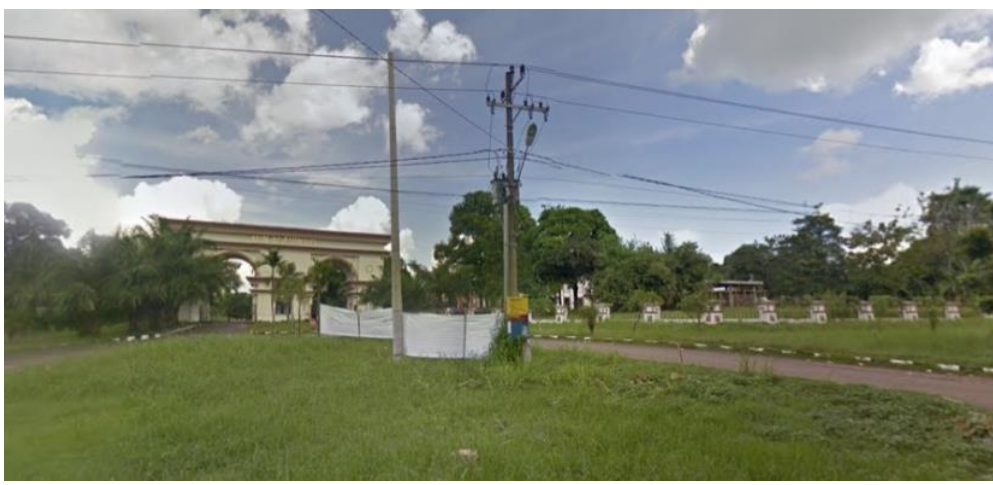

Gambar 5. Visual negatif pada segmen 4

Pada segmen 5 dengan fungsi bangunan perkuliahan dan lapangan olahraga, seharusnya lanskap hijau dapat dinikmati tanpa terhalang apapun. Namun secara faktual segmen ini juga termasuk segmen dengan penumpukan reklame yang berlebihan. Pandangan yang terbuka di sekitar lapangan olahraga menjadi penarik utama agar reklame dapat terbaca dengan cepat. Fungsi lapangan olahraga UIN Alauddin Makassar tidak hanya sebagai penunjang aktivitas mahasiswa melainkan unsur penting dalam sebuah lingkungan. Ruang terbuka hijau memiliki beberapa manfaat penting bagi sebuah kota dan merupakan unsur alamiah maupun binaan yang sangat berperan dalam mewujudkan kota yang berwawasan lingkungan (Brahmantyo, 2012). 


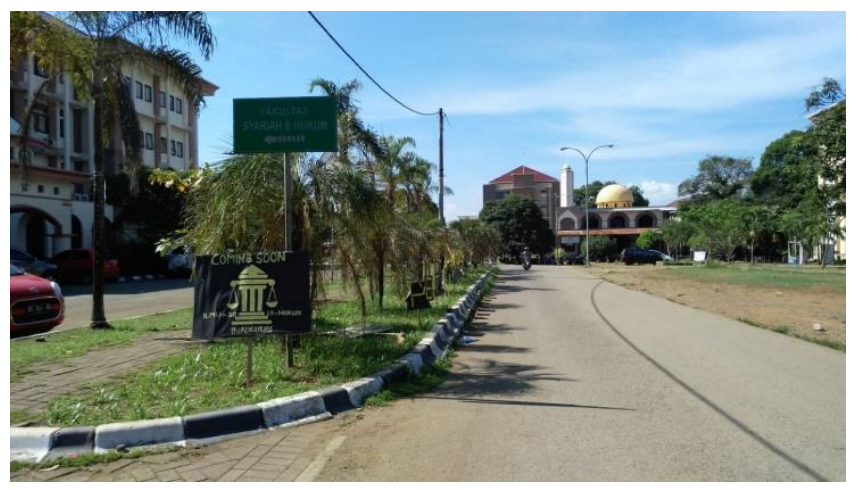

Gambar 6. Visual negatif pada segmen 5

Dampak visual negatif yang terjadi akibat tidak adanya kesesuaian teknis pemasangan dengan kondisi lingkungan sekitar, juga didorong dengan tidak tersedianya perangkat aturan yang mengatur secara teknis pemasangan reklame di kawasan Kampus II UIN Alauddin Makassar. Pemilihan lokasi penempatan umumnya dilakukan tanpa terkendali dan memunculkan kesan semrawut. Ruang yang dimanfaatkan untuk pemasangan reklame cenderung menghalangi pejalan kaki dan mengurangi jarak jangkauan pandangan pengendara. Jarak antarreklame yang terpasangan memiliki jarak kurang dari 10 meter mengakibatkan penumpukan pada beberapa titik.

\section{G. Penilaian Penempatan Reklame}

Untuk menentukan skala prioritas masing-masing segmen yang telah diidentifikasi, maka dibutuhkan kriteria dan indikator sebagai alat penilaian. Adapun metode perumusan kriteria dan indikator kawasan dapat dilakukan identiikasi kriteria dan indikator. AHP adalah prosedur yang berbasis matematis yang sangat baik dan sesuai untuk kondisi evaluasi atribut-atribut kualitatif. Atribut-atibut tersebut secara matematik dikuantitatif dalam satu set perbandingan berpasangan. Kelebihan AHP dibandingkan dengan metode lainnya adalah karena adanya struktur yang berhirarki, sebagai konsekuensi dari kriteria yang dipilih, sampai kepada sub-sub kriteria yang paling mendetail. Mempertimbangkan validitas sampai dengan batas toleransi inkonsistensi berbagai kriteria dan alternatif yang dipilih oleh para pengambil keputusan (Saaty, 1994).

Hasil analisis bobot dengan menggunakan AHP, kriteria yang sangat proritas dijadikan pedoman utama untuk pemilihan lokasi penyelenggaraan reklame dengan mencapai bobot 0.373 yaitu jenis penggunaan lahan pada kawasan Kampus II UIN Alauddin. Jenis penggunaan lahan dan fungsi bangunan akan mempengaruhi daya tarik penyelenggara untuk memasang reklame. Sedangkan kriteria kedua berdasarkan hasil analisis yaitu kriteria sirkulasi, sedangkan kriteria ketiga kondisi lanskap dan tampilan reklame dengan mencapai nilai bobot 0.215 dan kriteria keempat adalah kriteria teknis pemasangan reklame. Urutan prioritas penyelenggaraan reklame dalam Kampus II UIN Alauddin Makassar adalah sebagai berikut : 
Tabel 1. Tingkat prioritas kriteria

\begin{tabular}{clc}
\hline Tingkat Prioritas & \multicolumn{1}{c}{ Kriteria } & Nilai \\
\hline I & Klasifikasi penggunaan lahan & 0.373 \\
\hline II & Sistem sirkulasi & 0.335 \\
\hline III & Kondisi lanskap dan tampilan reklame & 0.215 \\
\hline IV & Aturan teknis pemasangan reklame & 0.078 \\
\hline
\end{tabular}

Sumber: Hasil analisis, 2018

Setelah melakukan penilaian kriteria yang digunakan dalam penataan reklame dalam kampus II UIN Alauddin Makassar, selanjutnya dilakukan analisis terhadap setiap segmen. Sehingga akan terpilih segmen yang prioritas untuk dijadikan sebagai segmen penempatan reklame. Penilaian ini dilakukan berdasarkan hasil pengisian kuesioner dari sampel penelitian yang digunkan dengan penilaian prioritas dalam 4 skala yaitu :

\begin{tabular}{|c|c|}
\hline Tidak prioritas & $:(0-0.74)$ \\
\hline Kurang prioritas & $:(0.75-1.4)$ \\
\hline Prioritas & $:(1.5-2.24)$ \\
\hline Sangat Prioritas & $:(2.25-3)$ \\
\hline
\end{tabular}

Hasil penilaian setiap segmen dapat menjadi alternatif kebijakan dalam menentukan segmen yang paling ideal sebagai lokasi penyelenggaraan reklame. Dari 7 segmen diperoleh segmen 2 dan segmen 4 dengan nilai kumulatif paling tinggi. Segmen 2 memperoleh nilai kumulatif 2.345 dan segmen 4 dengan nilai komulatif 2.404 . Sedangkan segmen 1 dan segmen 7 memiliki nilai kumulatif yang paling rendah, sehingga tidak dapat diarahkan sebagai area pemasangan reklame berdasarkan 4 kriteria yang telah ditentukan sebelumnya.

Dalam lanskap kawasan, penyelenggaraan reklame dapat mengacu pada tema setiap sub kawasan (segmen) sesuai dengan kesamaan karakter elemen-elemen pendukungnya yaitu penggunaan lahan, sirkulasi, kondisi bangunan, ruang terbuka dan jalur pedestrian (Juniarko, Surjono, \& Usman, 2010). Karakter streetscape ditentukan oleh elemen fisik pembentuk jalan dan aktivitas. Elemen yang berpengaruh membentuk karakter streetscape adalah geometri jalan yang terdiri dari dimensi dan konfigurasi bagian-bagian jalan, proporsi lebar jalan terhadap tinggi streetwall, bentuk jalan (alignment), karakter bangunan dan vegetasi di sepanjang jalan yang membentuk dinding pembatas jalan atau streetwall (Kogarah City Council, 2006; Carmona, 2007 dalam Hartanti (2014). Sedangkan aktivitas mencakup lalu lintas kendaraan dan aktivitas pejalan kaki serta fungsi bangunan yang mengindikasikan aktivitas di dalam bangunan serta interaksi dengan aktivitas diluar bangunan Mansouri (2009) dalam Hartanti (2014).

Segmen 2 memiliki karakter boulevard corridor dengan aktivitas kegiatan yang cukup tinggi dimana terdapat kegiatan perkantoran utama, segmen 4 mengacu pada gateway commercial corridor dengan kegiatan tinggi untuk penggunaan lahan komersial dan fasilitas umum. Sedangkan segmen 5 dan 6 terdapat public park dengan tata hijau mendominasi dengan vegetasi berupa pohon berkanopi lebar, sehingga menimbulkan kesan tenang, nyaman dan rindang sehingga sebaiknya dilakukan pembatasan pemasangan reklame agar visual lanskap hijau tetap terjaga. 
Tabel 2. Tingkat prioritas segmen

\begin{tabular}{clcl}
\hline \multicolumn{1}{c}{ Kriteria } & \multicolumn{1}{c}{ Fungsi Bangunan } & Nilai & Skala Prioritas \\
\hline Segmen 1 & $\begin{array}{l}\text { Fungsi sarana umum dan } \\
\text { perkantoran }\end{array}$ & 1.420 & Tidak prioritas \\
\hline Segmen 2 & $\begin{array}{l}\text { Fungsi bangunan perkantoran } \\
\text { (rektorat) dan lapangan upacara }\end{array}$ & 2.404 & Sangat prioritas \\
\hline Segmen 3 & Fungsi bangunan perkuliahan & 1.817 & Prioritas \\
\hline Segmen 4 & $\begin{array}{l}\text { Fungsi bangunan perkuliahan dan } \\
\text { sarana perdagangan dan jasa }\end{array}$ & 2.345 & Sangat prioritas \\
\hline Segmen 5 & $\begin{array}{l}\text { Fungsi bangunan perkuliahan dan } \\
\text { lapangan olahraga }\end{array}$ & 1.817 & Prioritas \\
\hline Segmen 6 & Fungsi campuran & 1.544 & Prioritas \\
\hline Segmen 7 & Fungsi bangunan perkuliahan & 1.410 & Tidak prioritas \\
\hline Sumber: Hasil analisis, 2018 & &
\end{tabular}

\section{H. Arahan Penyelenggaraan Reklame}

Dalam rangka mewujudkan visi UIN Alauddin Makassar sebagai Pusat Pencerahan dan Transformasi Ipteks Berbasis Peradaban Islam berdasarkan tujuan yang ingin dicapai pada terciptanya sistem manajemen, kepemimpinan dan kelembagaan yang sehat serta terwujudnya tata ruang, lingkungan dan iklim kampus yang islami maka perlu dilakukan penyelenggaraan reklame yang berwawasan islami. Upaya yang perlu dilakukan adalah :

1. Menetapkan lokasi pemasangan reklame pada 2 segmen inti yaitu segmen 2 dan 4

2. Menyusun sistem aturan teknis tentang penyelenggaraan pemasangan reklame mulai dari ukuran, bentuk, tampilan, bahasa hingga media yang digunakan

3. Menerbitkan sistem alur pemasangan reklame berbasis web mulai dari verifikasi materi reklame, jadwal publikasi hingga pembatalan publikasi reklame

4. Menyediakan media pemasangan reklame dalam 1 wadah yang saling terintgerasi misalnya layar LCD yang mampu terjangkau dari pandangan mata, kemudian memuat seluruh informasi secara bergantian. Sehingga media pamflet, umbulumbul dan poster tidak terpasang secara berlebihan.

\section{KESIMPULAN}

Penyelenggaraan reklame di Kawasan Kampus II UIN Alauddin Makassar didominasi oleh reklame non permanen yang terpasang secara bersiklus. Kepadatan reklame terjadi pada siklus bulan Agustus - Desember setiap tahunnya. Pemasangan reklame cenderung tidak beraturan dan tidak sesuai dengan teknis pemasangan terhadap kondisi lingkungan sekitar. Kondisi ini mendorong munculnya visual negatif pada 4 segmen yang mempunyai fungsi bangunan penting dan nilai vital dalam lingkungan kampus. Jika citra visual dari 4 segmen ini mengalami kerusakan maka secara keseluruhan citra visual kampus bernilai buruk. Lokasi penyelenggaraan reklame diprioritaskan pada segmen 2 dengan fungsi perkantoran dan lapangan upacara sedangkan segmen 4 dengan fungsi gedung perkuliahan dan perdagangan / jasa. Kedua segmen ini memenuhi kriteria penempatan reklame dibandingkan dengan beberapa segmen lainnya. Namun perlu penataan dan pengendalian yang sebaik mungkin agar reklame yang terpasang tidak menganggu citra visual pada kedua segmen ini. Beberapa 
hal yang perlu dipertimbangkan dalam pengelolaan reklame di kampus UIN Alauddin Makassar adalah

1. Perlu dilakukan pengaturan zonasi penempatan reklame berikut perangkat yang mengatur alur publikasinya

2. Pelaksanaan aturan yang tegas terhadap pelanggaran pemasangan reklame yang tidak bersesuain dengan lokasi yang telah diarahkan

3. Aspek isi pesan reklame seharusnya mendidik pengamat dengan menggunakan katakata yang baik dan benar.

\section{DAFTAR PUSTAKA}

Branch, M. C. (1996). Perencanaan Kota Komprehensif, Pengantar dan Penjelasan. Yogyakarta: Gadjah Mada University Press.

Budiono, T. (2011). Analisis Viasual terhadap keberadaan Reklame pada Lanskap Jalur. Bogor: Skripsi Institut Pertanian Bogor.

David, F. R. (2009). Stategic Management : Consept and Cases. New Jersey: Prenctice Hall.

Djayaningrat, S. T. (2011). Ekonomi Hijau. Bandung: Rekayasa Sains.

Hamidi. (2011). Aplikasi Sistem Informasi Geografis Berbasis Web Penyebaran Bantuan. Jurnal Masyarakat Informatika , 1-14.

Hartanti, N. B. (2014). Karakter Streetscape sebagai Pembentuk Identitas Kota Bogor. Seminar Nasional Riset Arsitektur dan Perencanaan (SERAP) 3 (pp. 1-14). Yogyakarta: Jurusan Teknik Arsitektur dan Perencanaan Universitas Gadjah Mada.

Juniarko, O., Surjono, \& Usman, F. (2010). Penataan Reklame pada Koridor Jalan Utama Kota Mataram. Jurnal Tata Kota dan Daerah, 83-86.

Kusrini. (2007). Konsep dan Aplikasi Sistem Pendukung Keputusan. Yogyakarta: Andi.

Lukman, A. (2017). Peran Pajak Reklame dalam Upaya Meningkatkan Pendapatan Asli. Yogyakarta: Skripsi Universitas Muhammdiyah.

Saaty, T. L. (1994). How to Make a Decision : The Analytic Hierarchy. London: Institute for Operations Research and the Management Science.

Syaifullah. (2010). Pengenalan Metode AHP (Analytical Hierarchy Process). Jakarta: Dimensi. 